\title{
Calculation of Exergy Destruction of Various Components by Performing Exergy Analysis on Stage-I of Dr. Narla Tatarao Thermal Power Station (N.T.T.P.S)
}

\author{
N Naga Varun, T Subba Reddy, T L Prasannna Kumar, S P Krishna Mithra, M Srinivasa Reddy
}

\begin{abstract}
For any nation to develop power generation plays a crucial role. The performance of a power plant is analyzed by using the Energy balance and it is done by using the first law of thermodynamics. But to know how much energy is being utilized in reality exergy analysis has to be performed which is also called as second law of thermodynamic analysis because the vital parameter quality is being considered in the exergy analysis. this paper deals with the exergy destruction calculation by performing exergy analysis for various components for a $210 \mathrm{mw}$ plant of Vijayawada thermal power station(stage-1 unit-1) and from the analysis it is clear that exergy destruction is more in condenser

Keywords: Available Energy, Exergetic destruction, second law efficiency.
\end{abstract}

\section{INTRODUCTION}

With the increase in the global warming along with food clothing and shelter one particular parameter playing an important role along with these basic needs that is POWER and it so essential which the life style is not at all an issue. Our country depends on both renewable and non renewable sources but the major part is occupied by conventional source that is coal.. It is used in a thermal power plant which drives the prime mover. From the facts and figures around $58.75 \%$ to $60 \%$ the power generation is from coal. Around $8.91 \%$ is from natural gas where as oil and nuclear contribute to $0.52 \%$ and $2.11 \%$. $66.8 \%$ is from coal and petroleum. The percentage of crude oil expected around $7 \%$ and $22 \%$ by 2021-22. [1]

Revised Manuscript Received on December 30, 2019.

* Correspondence Author

N Naga Varun, Mechanical Department, Andhra Loyola Institute of Engineering, Technology, Vijayawada, (A.P.) India.

nandurivarun@gmail.com

T Subba Reddy, Mechanical Department, Andhra Loyola Institute of Engineering, Technology, Vijayawada, (A.P.) India. phdsbbareddy@gmail.com

T L Prasanna Kumar, Mechanical Department, Andhra Loyola Institute of Engineering, Technology, Vijayawada, (A.P.) India.

kumar.me326@gmail.com

M Srinivasa Reddy, Mechanical Department, Andhra Loyola Institute of Engineering, Technology, Vijayawada, (A.P.) India. srinivas060788@gmail.com

S P Krishna Mithra, Mechanical Department, Andhra Loyola Institute of Engineering and Technology, Vijayawada, (A.P.) India.

spkmithra@gmail.com

(c) The Authors. Published by Blue Eyes Intelligence Engineering and Sciences Publication (BEIESP). This is an open access article under the CC BY-NC-ND license (http://creativecommons.org/licenses/by-nc-nd/4.0/)
To measure the life style of the people we have so many indicators to measure among them the power consumption is one which shows the living standards of the people. This particular papers deals with the evaluation of exergy destruction and calculation of second law efficiency.

Why because in general the power plant efficiency is valuated with the help of energy analysis which is on $1^{\text {st }}$ law of T.D which in general will not consider the quality of the energy there by will not be getting the correct analysis of the performance which is simply a energy balance.

Here we will be calculating the exergy destruction on $2^{\text {nd }}$ law of thermodynamics, which considers the energy quality. The $1^{\text {st }}$ and $2^{\text {nd }}$ analysis will provide a complete picture to improve the plant efficiency

\section{INDIVIDUAL COMPONENTS}

A. Boiler: used to convert water into steam

B. Super-heater: to ensure that only dry steam is entering into the turbine.

C. Re-heater: to make sure that dry steam is entering into intermediate pressure turbine after the expansion in the high pressure turbine

D. : the purpose is to heat the water coming from condenser in advance before reaching the boiler by which fuel supply rate can be decreased [2]

E. Turbines: In thermal power plants, the turbine takes the steam as input and gives power as output.

F. Deaerator: Is to remove any air and dissolved gases.

G. Condenser: This converts water into steam

H. Feed water Heater:

Like economizer feed water heaters are used to heat the water coming from the condenser by tapping the turbines.

\section{MODELLING OF EXERGY}

\section{Exergy Modelling For Thermal Components}

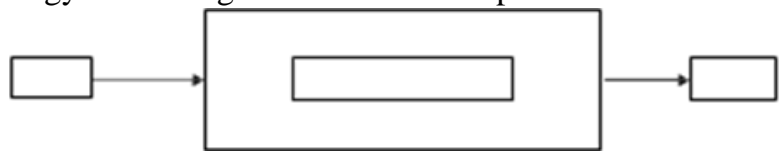

Specific Exergy for any component is given by

$\varphi=\left(h-h_{0}\right)-T_{0}\left(s-s_{0}\right)---\rightarrow 1$

Where $h_{0}, s_{0}, T_{0}$ indicates reference states 
Calculation of Exergy Destruction of Various Components by Performing Exergy Analysis on Stage-I of Dr. Narla Tatarao Thermal Power Station (N.T.T.P.S)

Overall Exergy:

$\dot{X}=\dot{m}\left[\left(h-h_{0}\right)-T_{0}\left(s-s_{0}\right)\right]--\rightarrow 2$

$\dot{m}$ implies flow rate.

Inlet exergy $=$

Exin $=\dot{m}\left[h_{1}-h_{0}-T_{0}\left(S_{1}-S_{0}\right)\right]--\rightarrow 3$

Outlet Exergy=

Exout $=\dot{m}\left[h_{2}-h_{0}-T_{0}\left(S_{2}-S_{0}\right)\right]---\rightarrow 4$

Destruction of Exergy $(\mathrm{I})=$

$$
\mathrm{I}=\mathrm{Ex}_{\mathrm{in}}-\mathrm{Ex}_{\text {out }^{-}} \mathrm{W}
$$

\%Destruction of Exergy $=($ Destruction in Exergy/Overall Destruction in energy of the cycle) $* 100---\rightarrow 6$

$2^{\text {nd }}$ law efficiency is

1. Original W.D to Ideal work ${ }^{[3]}$

\section{$\eta_{I I}=\frac{\text { Actual work done }}{\text { Maximum theoritical work }}------\rightarrow$ \\ 7}

In other terms

2. Original thermal efficiency to the maximum possible thermal efficiency ${ }^{[4]}$

$$
\eta_{I I}=\frac{\text { Exergy output }}{\text { Exergy input }}
$$

\section{TURBINE LAYOUT}

The turbine house and remaining components of Dr N.T.T.P.S are shown in the below figure 2. Along with the figure the operating parameters are also shown by using the above mentioned equations. Thus the obtained results are tabulated in Table 1, 2 and 3

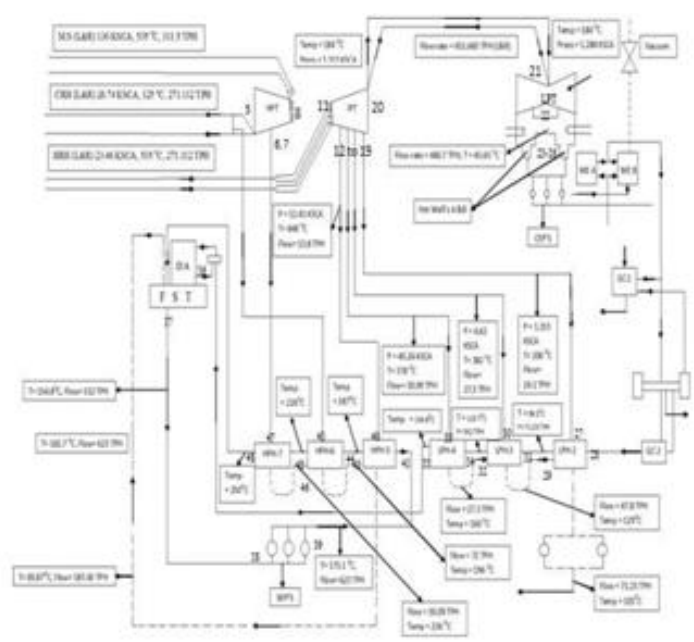

Table-I Showing Exergy, Percentage Of Exergy Destruction And Second Law Efficiency

\begin{tabular}{|l|c|c|c|c|}
\hline \multicolumn{2}{|c|}{ Loading } & \multicolumn{3}{c|}{ @ 95\% loading } \\
\hline \multicolumn{2}{|c|}{ Components } & $\begin{array}{c}\text { Exergy } \\
\text { destruction(M } \\
\text { W) }\end{array}$ & $\begin{array}{c}\text { Percent } \\
\text { age exergy } \\
\text { destruction } \\
(\%)\end{array}$ & $\begin{array}{c}2^{\text {nd }} \\
\text { Law } \\
\text { efficie } \\
\text { ncy } \\
(\%)\end{array}$ \\
\hline $\begin{array}{l}\text { High } \\
\text { Pressure } \\
\text { Turbine }\end{array}$ & S-1 & 61.59 & 24.11 & 89. \\
& S-2 & 8.35 & 3.26 & 03 \\
68. \\
\end{tabular}

\begin{tabular}{|c|c|c|c|c|}
\hline \multirow{4}{*}{ Intermedi } & S-1 & 29.97 & 11.73 & 90. \\
ate Pressure & S-2 & 24.396 & 9.55 & 28 \\
& S-3 & 33.049 & 12.94 & 84. \\
& S-4 & 12.518 & 4.90 & 07 \\
& S-5 & 4.954 & 1.94 & 98. \\
& & & & 99 \\
& & & & 93. \\
& & & & $\begin{array}{c}76 \\
80 .\end{array}$ \\
\hline Low & S-1 & 50.99 & 19.96 & 62. \\
Pressure \\
Turbine
\end{tabular}

Table II Components And Second Law Efficiencies

\begin{tabular}{|c|c|c|}
\hline \multicolumn{2}{|c|}{ COMPONENT } & $\begin{array}{c}\text { SECOND LAW } \\
\text { EFFICIENCY (\%) }\end{array}$ \\
\hline \multicolumn{2}{|c|}{ Boiler } & $40.20 \%$ \\
\hline \multirow{4}{*}{ Heaters } & LPH 2 & $21.45 \%$ \\
\cline { 2 - 3 } & LPH 3 & $63.69 \%$ \\
\cline { 2 - 3 } & LPH 4 & $86.56 \%$ \\
\cline { 2 - 3 } & HPH 5 & $90.65 \%$ \\
\cline { 2 - 3 } & HPH 6 & $97.59 \%$ \\
\cline { 2 - 3 } & HPH 7 & $99.84 \%$ \\
\hline \multirow{4}{*}{ surbine } & HPT & $94.89 \%$ \\
\cline { 2 - 3 } & IPT & $77.06 \%$ \\
\cline { 2 - 3 } & LPT & $89.05 \%$ \\
\cline { 2 - 3 } & & $62.14 \%$ \\
\hline
\end{tabular}


Table:III Showing Exergy Values For Various Components

\begin{tabular}{|c|c|c|c|c|c|c|c|c|}
\hline Economizer inlet & 1 & 247 & 145 & 173.05 & 1071.81 & 2.741 & 258.99 & 44.81 \\
\hline Economizer outlet & 2 & 278 & 137 & 173.05 & 1205.16 & 3.026 & 306.84 & 53.09 \\
\hline S.H inlet & 3 & 345 & 128 & 173.05 & 2930 & 5.9 & 1169.48 & 202.37 \\
\hline S.H Outlet & 4 & 535 & 128 & 173.05 & 3430.12 & 6.561 & 1471.3 & 254.6 \\
\hline HPT inlet & 5 & 535 & 128 & 173.05 & 3430.12 & 6.561 & 1471.3 & 254.6 \\
\hline Tapping & 6 & 378 & 40 & 173.05 & 3113.23 & 6.6911 & 1115.38 & 193.01 \\
\hline Tapping & 7 & 378 & 40 & 165 & 3113.23 & 6.6911 & 1115.38 & 184.03 \\
\hline HPT Outlet & 8 & 330 & 26 & 165 & 3078.62 & 6.7444 & 1064.78 & 175.68 \\
\hline R.H Inlet & 9 & 330 & 26 & 165 & 3078.62 & 6.7444 & 1064.78 & 175.67 \\
\hline R.H outlet & 10 & 535 & 23 & 154.20 & 3539.87 & 7.459 & 1311.85 & 202.02 \\
\hline IPT Inlet & 11 & 535 & 23 & 154.20 & 3539.87 & 7.459 & 1311.85 & 202.02 \\
\hline Tapping 1 & 12 & 448 & 12 & 154.20 & 3364.39 & 7.522 & 1117.23 & 172.05 \\
\hline tapping 1 & 13 & 448 & 12 & 150.36 & 3364.39 & 7.522 & 1117.23 & 167.986 \\
\hline Tapping 2 & 14 & 380 & 6.5 & 150.36 & 3227.98 & 7.6081 & 955.03 & 143.59 \\
\hline Tapping 2 & 15 & 380 & 6.5 & 143 & 3227.98 & 7.6081 & 955.03 & 136.56 \\
\hline Tapping 3 & 16 & 265 & 2.8 & 143 & 2999.18 & 7.616 & 723.86 & 103.511 \\
\hline Tapping 3 & 17 & 265 & 2.8 & 137.5 & 2999.18 & 7.616 & 723.86 & 99.530 \\
\hline Tapping 4 & 18 & 200 & 1.5 & 137.5 & 2872.9 & 7.644 & 589.18 & 81.012 \\
\hline Tapping 4 & 19 & 200 & 1.5 & 130.80 & 2872.9 & 7.644 & 589.18 & 77.064 \\
\hline IPT outlet & 20 & 184 & 1.3 & 130.80 & 2842.3 & 7.668 & 551.31 & 72.11 \\
\hline LPT inlet & 21 & 184 & 1.3 & 130.80 & 2842.3 & 7.668 & 551.31 & 72.11 \\
\hline LPT Outlet & 22 & 50 & 0.1 & 130.80 & 2600 & 8.16 & 161.48 & 21.12 \\
\hline \multirow{2}{*}{$\begin{array}{l}\text { Condenser inlet1 } \\
\text { Condenser inlet } 2\end{array}$} & 23 & 50 & 0.1 & 130.80 & 2600 & 8.16 & 161.48 & 21.12 \\
\hline & 24 & 30 & 1.013 & 808 & 125.83 & 0.436 & 4.21 & 3.40 \\
\hline \multirow{2}{*}{$\begin{array}{l}\text { Condenser outlet } 1 \\
\text { Condenser outlet } 2\end{array}$} & 25 & 45 & 0.1 & 130.80 & 191.8 & 0.649 & 6.58 & 0.860 \\
\hline & 26 & 40 & 1.013 & 808 & 167.62 & 0.572 & 5.5 & 4.44 \\
\hline $\begin{array}{l}\text { DEAERATOR } \\
\text { INLET }\end{array}$ & 27 & 154.5 & 8.5 & 147.7 & 651.9 & 1.887 & 95.28 & 14.07 \\
\hline $\begin{array}{l}\text { DEAERATOR } \\
\text { OUTLET }\end{array}$ & 28 & 165 & 7.16 & 173.05 & 697.35 & 1.992 & 109.23 & 18.90 \\
\hline BFP INLET & 29 & 165 & 7.16 & 173.05 & 697.35 & 1.992 & 109.23 & 18.90 \\
\hline BFP OUTLET & 30 & 165 & 155 & 173.05 & 705.889 & 1.974 & 123.169 & 21.31 \\
\hline
\end{tabular}


Calculation of Exergy Destruction of Various Components by Performing Exergy Analysis on Stage-I of Dr. Narla Tatarao Thermal Power Station (N.T.T.P.S)

Table:IV Showing Exergy Values For Low Pressure Heaters

\begin{tabular}{|c|c|c|c|c|c|c|c|}
\hline COMPONENTS & $\mathrm{T}\left({ }^{\circ} \mathrm{C}\right)$ & P (bar) & $\begin{array}{c}0 \\
\mathrm{~m}(\mathrm{~kg} / \mathrm{s})\end{array}$ & $\mathrm{H}(\mathrm{kJ} / \mathrm{kg})$ & $\begin{array}{l}\text { Entropy } \\
(\mathrm{kJ} / \mathrm{kgK})\end{array}$ & $\begin{array}{c}\Psi \\
(\mathrm{kJ} / \mathrm{kg})\end{array}$ & $\begin{array}{c}\mathrm{O} \\
\mathrm{X} \\
(\mathrm{MW}) \\
\end{array}$ \\
\hline \multirow{2}{*}{$\begin{array}{l}\text { LPH } 2 \text { inlet 1(S) } \\
\text { LPH } 2 \text { inlet } 2(\mathrm{~W})\end{array}$} & 200 & 1.5 & 6.69 & 2872.9 & 7.644 & 589.18 & 3.94 \\
\hline & 87 & 16.68 & 130.80 & 365.60 & 1.156 & 28.28 & 3.69 \\
\hline LPH 2 Outlet & 99.3 & 13.7 & 130.80 & 417.10 & 1.298 & 37.18 & 4.86 \\
\hline \multirow{2}{*}{$\begin{array}{l}\text { LPH } 3 \text { inlet } 1(\mathrm{~S}) \\
\text { LPH } 3 \text { inlet } 2(\mathrm{~W})\end{array}$} & 265 & 2.78 & 5.5 & 2999.18 & 7.616 & 723.86 & 3.98 \\
\hline & 106 & 13.7 & 130.80 & 417.10 & 1.298 & 37.18 & 5.60 \\
\hline LPH 3 Outlet & 120 & 12 & 147.7 & 504.48 & 1.526 & 50.10 & 8.29 \\
\hline \multirow{2}{*}{$\begin{array}{l}\text { LPH } 4 \text { inlet } 1(\mathrm{~S}) \\
\text { LPH } 4 \text { inlet } 2(\mathrm{~W})\end{array}$} & 381.5 & 6.49 & 7.23 & 3227.98 & 7.6081 & 955.03 & 7.23 \\
\hline & 120 & 12 & 147.7 & 504.48 & 1.526 & 50.10 & 8.29 \\
\hline LPH 4 Outlet & 154.5 & 8.5 & 147.7 & 651.90 & 1.887 & 95.28 & 14.07 \\
\hline
\end{tabular}

Table:V Showing Exergy Values For High Pressure Heaters

\begin{tabular}{|c|c|c|c|c|c|c|c|}
\hline COMPONENTS & $\mathrm{T}\left({ }^{\circ} \mathrm{C}\right)$ & P (bar) & $\begin{array}{c}\mathrm{o} \\
\mathrm{m}(\mathrm{kg} / \mathrm{s})\end{array}$ & $\mathrm{H}(\mathrm{kJ} / \mathrm{kg})$ & $\begin{array}{l}\text { Entropy } \\
(\mathrm{kJ} / \mathrm{kgK})\end{array}$ & $\begin{array}{c}\Psi \\
(\mathrm{kJ} / \mathrm{kg})\end{array}$ & $\begin{array}{c}\mathrm{O} \\
\mathrm{X} \\
(\mathrm{MW})\end{array}$ \\
\hline HPH 5 inlet 1(S) & 448 & 12.17 & 3.83 & 3364.39 & 7.522 & 1117.27 & 4.282 \\
\hline HPH 5 inlet 2(W) & 173.1 & 155 & 173.05 & 740.81 & 2.053 & 134.39 & 23.25 \\
\hline HPH 5 Outlet & 187 & 150 & 173.05 & 804.03 & 2.194 & 155.31 & 26.87 \\
\hline HPH 6 inlet 1(S) & 325 & 26.24 & 10.49 & 3066.75 & 6.7249 & 1058.76 & 11.1 \\
\hline HPH 6 inlet 2(W) & 187 & 150 & 173.05 & 804.03 & 2.194 & 155.31 & 26.87 \\
\hline HPH 6 Outlet & 226 & 147.2 & 173.05 & 974.63 & 2.55 & 219.11 & 37.91 \\
\hline HPH 7 inlet $1(\mathrm{~S})$ & 378 & 39.5 & 8.35 & 3113.23 & 6.6911 & 1115.38 & 9.313 \\
\hline HPH 7 inlet 2(W) & 226 & 147.2 & 173.05 & 974.63 & 2.55 & 219.11 & 37.91 \\
\hline HPH 7 Outlet & 247 & 145 & 173.05 & 1071.81 & 2.741 & 258.99 & 44.81 \\
\hline
\end{tabular}

\section{RESULT ANALYSIS AND DISUCSSIONS}

In this study the exergetic analysis of $210 \mathrm{MW}$ plant of Dr N.T.T.P.S is performed. With the obtained values which are shown in the tables 3, 4and 5. The exergy destruction percentage, $2^{\text {nd }}$ law efficiency and the destruction of exergy is calculated and are shown in the table 1 and 2. All the calculations are done at $95 \%$ condition and the graphs are plotted and are shown below and in tables 1 and 2

The second law efficiency is more for High Pressure Heater and can be observed from graph 4.In the power generating components it is found to be high for INTERMEDIATE PRESSURE TURBINE and Low Pressure Turbine is having low efficiency. This shows both these components are having higher entropy generation rate and there is room for improvement. The destruction in exergy is more in condenser the reason is it runs at low temperature and so as the work capacity. Even the amount of losses in the exergy is more we will not consider because of its quality of energy which is low. Graphs are drawn between

- Components Vs Exergy Efficiency

- Components Vs Exergy Destruction

- Components Vs Percentage Exergy Destruction

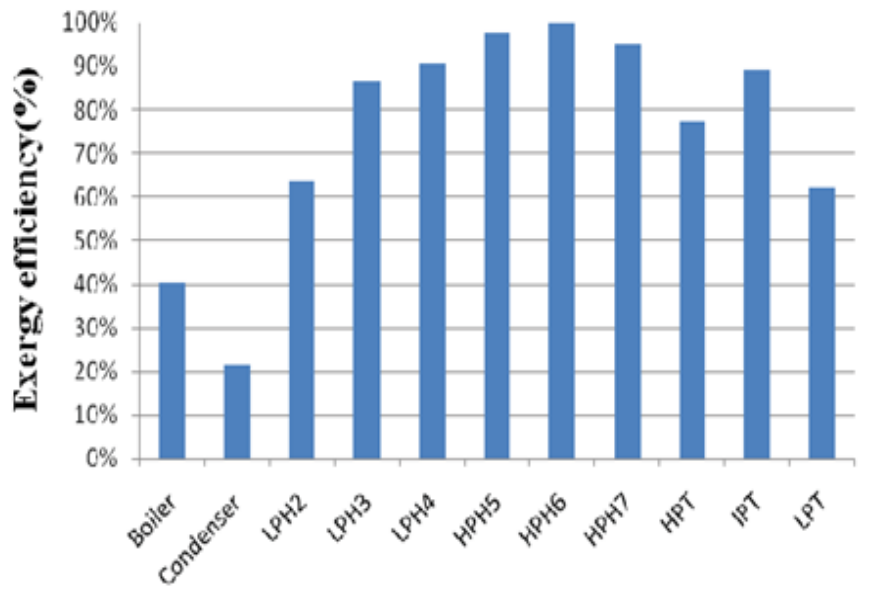

Components 

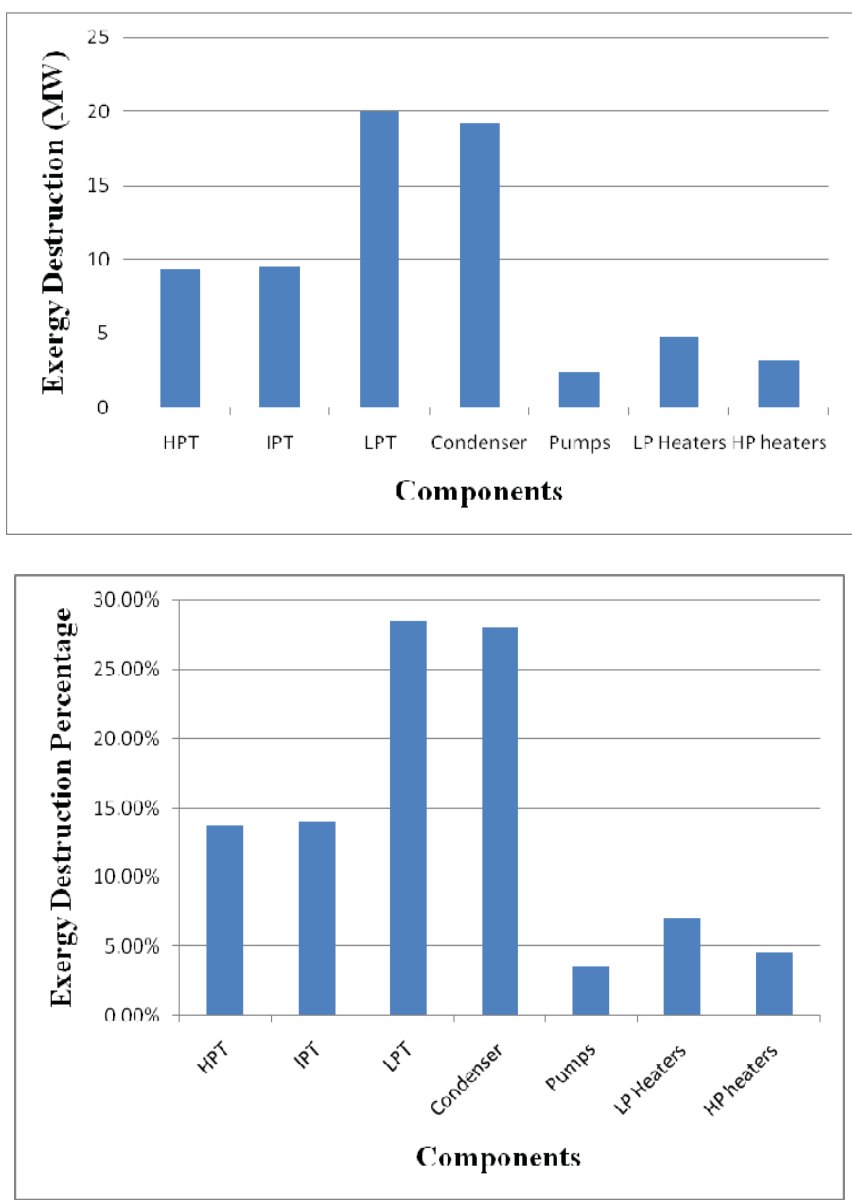

\section{CONCLUSIONS}

The Exergy destruction for a $210 \mathrm{MW}$ plant of V.T.P.S has been performed and it can be seen that the condenser is having the highest exergy destruction rate and there is scope for improvement but practically its feasibility is low because of its Physical and environmental factors.

\section{NOMENCLATURE}

$\mathrm{h}=$ Specific enthalpy $(\mathrm{J} / \mathrm{kg})$

$\mathrm{s}=$ Specific entropy $(\mathrm{J} / \mathrm{kgK})$

$\mathrm{h}_{\mathrm{o}}=$ Specific enthalpy at ambient condition $(\mathrm{J} / \mathrm{kg})$

$\mathrm{S}_{\mathrm{o}}=$ Specific entropy at ambient condition $(\mathrm{J} / \mathrm{kgK})$

$\dot{I}=$ Exergy destruction rate (W)

$\mathrm{T}=$ Temperature $\left({ }^{\circ} \mathrm{C}\right)$

$m^{*}=$ Mass flow rate $(\mathrm{kg} / \mathrm{s})$

$\overrightarrow{W^{\prime}}=$ Work done rate or power done by the system (W)

$\mathrm{P}=$ Pressure (bar)

$\dot{X}=$ Total energy rate (W)

$\mathrm{Q}=$ Heat transfer rate to the system (W)

\section{SYMBOLS}

\section{$\eta_{I I}=$ Efficiency}

$\Psi=$ Specific Exergy $(\mathrm{J} / \mathrm{kg})$

\section{REFERENCES}

1. http://en.wikipedia.org/wiki/Energy_policy_of_India

2. http://www.slideshare.net/AnkurMahajan1/power-scenario-in-india

3. http://mospi.nic.in/mospi_new/upload/Energy_Statistics_2013.pdf?sta tus=1\&menu_id=216

4. http://www.ivt.ntnu.no/ept/fag/tep4215/innhold/Kotas\%20-\%20The\% 20Exergy\%20Method\%20of\%20Thermal\%20Plant\%20Analysis.pdf
5. http://hassam.hubpages.com/hub/Types-Of-Turbines

6. https://docs.google.com/document/d/1oCi_jHWfH5y9ppJzhBZmx6c DVJKyoB_5ZFBkSvVbj4I/edit?hl=en_US

7. Yadav R., 'Steam and gas turbines and power plant engineering', 2nd edn., Central Publishing House Allahabad,2007, Vol. 1, pp7-8.

\section{AUTHORS PROFILE}

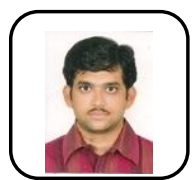

N Naga Varun Currently working as an Assistant professor in the department of Mechanical Engineering in ALIET. Bachelors Degree from KLCE and Masters Degree from KLU with Specialization in thermal Engineering

T Subba Reddy Currently working as Assistant professor in the department of Mechanical Engineering in ALIET. Bachelors Degree from ALIET and Masters Degree from NIET with Specialization in CAD/CAM Engineering and pursuing $\mathrm{PhD}$ from visweswarayya technological university, Karnataka. He was member of international association of engineers.

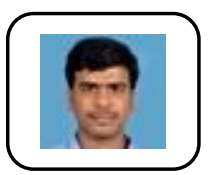

T L Prasanna Kumar Currently working as an Assistant professor in the department of Mechanical Engineering in ALIET. Bachelors Degree from St Ann's and Masters Degree from Vanmayi College of Engineering JNTU H with Specialization in Production Engineering

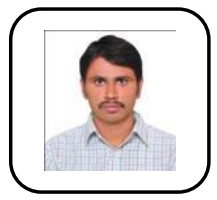

M Srinivasa Reddy Currently working as an Assistant professor in the department of Mechanical Engineering in ALIET. Bachelors Degree from Vignan college of Engineering and Masters Degree from SRM University Chennai with Specialization in Production Engineering

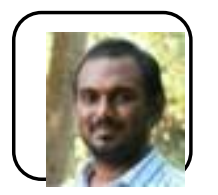

S P Krishna Mithra Currently working as an Assistant professor in the department of Mechanical Engineering in ALIET. Bachelors Degree from KLCE and Masters Degree from JNTU K with Specialization in CAD/CAM. 